\title{
Helen Lester
}

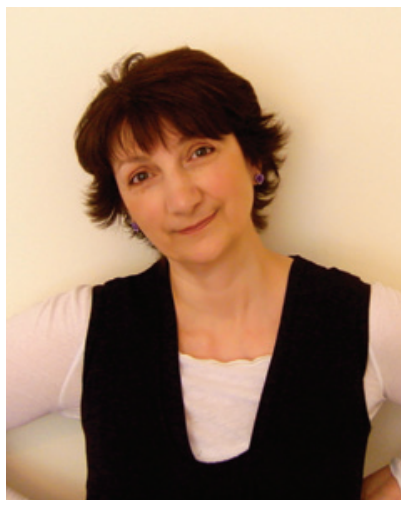

\section{REFERENCES}

1. Bevan A. In place of Fear. New York, NY: Simon and Schuster, 1952: 79.

2. Hacking JM, Muller S, Buchan I. Trends in mortality from 1965-2008 across the English north-south divide: comparative observational study. BMJ 2011; 342: d508.

3. Whitehead M, Doran T. The north-south divide. The NHS must do more than pick up the pieces. BMJ 2011; 342: d584.

4. The Marmot Review. Fair society, healthy lives Strategic review of health inequalities in England post-2010. London: The Marmot Review, 2010

5. Engels F. The condition of the working class in England in 1844. Charleston, SC: Bibliobazaar, 2007

DOI: 10.3399/bjgp11X572526

\section{Good enough care?}

One wintry Sunday afternoon in the bad old days, I was part of the interview panel for prospective new partners in my husband's practice. We had just moved into the area and had no one we trusted to look after our 10-month old son, so he came with us. As I sat there in the consulting room, with number one son dibbling around behind me, the (eventually successful) candidate asked me if I minded that he was sucking the KY Jelly tube on the trolley. Not for the first time, the notion of the good enough mother' popped into my head.

Donald Winnicott's ideas of being 'good enough' were my constant companion in the 1990s, kept the working-mother guilt at bay (just), and occasionally helped me during difficult consultations. Then a new song started to be sung in my academic world, one of gold standards, of centres of excellence, of being the brightest and the best. There are now echoes of this on the frontline in talk of 150 quality standards, of beacons, of pathfinders. So this got me thinking, what are we aiming for - in our brave new commissioning world - are we to be this good or will good enough do?

Aneurin Bevan stated very clearly that we need to aim for the best:

Society becomes more wholesome more serene, and spiritually healthier, if it knows that its citizens have at the back of their consciousness the knowledge that not only themselves, but all their fellows, have access, when ill, to the best that medical skill can provide."

Ah, you'll say, but that was 60 years ago and we've moved on you know. We've spent so much on health, the infrastructure is there, we have excellent NHS staff, and our social medicine model is the envy of the world. Good enough is fine now isn't it?

There was a paper in the BMJ in February this year that found that since 1965, the English north-south health divide in terms of premature mortality has continued to widen. ${ }^{2}$ The toll of excess death has now exceeded 1.5 million people, with the north being decimated at the rate of a major city every decade. ${ }^{3}$ The underlying causes are both social and economic and to help address these heart-stopping statistics, primary care consortia need to be a lot more than good enough. We need to make sure our links with local authorities are not afterthoughts but central to discussions, the presence of individuals and ideas from that sector seen as a marker of high quality commissioning groups. Public health needs to be centre stage in all commissioning consortia, north, south, east, and west. Marmot's seminal work last year on health inequalities talked about proportionate universalism' - that is, actions must be proportionate to the degree of disadvantage, and hence applied in some degree to all people, and not just the most disadvantaged. ${ }^{4}$

And a final thought on why 'good enough' can no longer do. Friedrich Engels, pacing the streets of Manchester and Liverpool in the mid-19th century made an observation that ought to feature in each new commissioning group's meeting room:

'When one individual inflicts bodily injury upon another, such injury that death results, we call the deed manslaughter; when the assailant knew in advance that the injury would be fatal, we call his deed murder. But when society places hundreds of proletarians in such a position that they inevitably meet a too early and an unnatural death ... knows that these thousands of victims must perish, and yet permits these conditions to remain, its deed is murder just as surely as the deed of the single individual; disguised malicious murder.'

Let us be good, not good enough.
ADDRESS FOR CORRESPONDENCE

E-mail: Helen.Lesteramanchester.ac.uk 